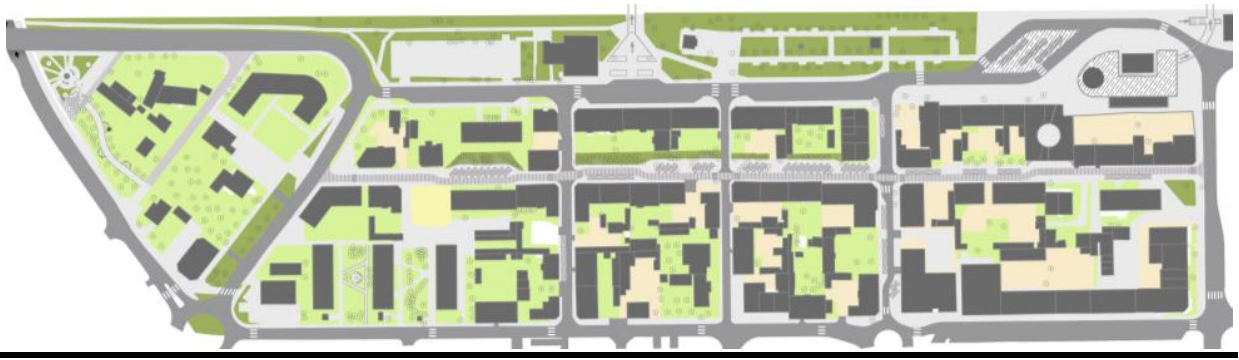

DOI: 10.21005/pif.2021.48.C-07

\title{
THE ROLE OF A TWO-STAGE QUESTIONNAIRE IN THE URBAN DESIGN PROCESS
}

\author{
ROLA ANKIETY DWUETAPOWEJ \\ W PROCESIE PROJEKTOWANIA URBANISTYCZNEGO
}

\author{
Łukasz Rosiak \\ Mgr inż. arch. \\ Author's Orcid number: 0000-0001-8823-0430 \\ Politechnika Bydgoska im. Jana i Jędrzeja Śniadeckich \\ Wydział Budownictwa, Architektury i Inżynierii Środowiska \\ Katedra Architektury i Urbanistyki
}

\begin{abstract}
The aim of the article is to present how urban planners use the potential of a questionnaire. The intention of the designers is to incorporate this study into two different phases of urban design. The first will be a questionnaire relating to the diagnosis of the condition. The second test will be performed at a later stage of works, during the assessment of spatial solutions. This questionnaire will be an assessment of spatial solutions. In the article, the author in this work, will try to explain the important this research technique is in the decision-making process of urban design. For this purpose, he will use the example of developing a local revitalization plan for the so-called "Old Town" of the city of Wołomin.
\end{abstract}

Key words: questionnaire, participatory design, space, urban planning.

\section{STRESZCZENIE}

Artykuł ma na celu zaprezentowanie w jaki sposób urbaniści wykorzystują potencjał badania ankietowego. W zamierzeniu projektantów jest włączenie tego badania do dwóch różnych faz projektowania urbanistycznego. Pierwszą z nich będzie ankieta odnosząca się do diagnozy stanu. Drugie badanie wykonywane będzie na późniejszym etapie prac, podczas oceny rozwiązań przestrzennych. Autor w niniejszej pracy będzie się starał wyjaśnić jak jest ważna ta technika badawcza w procesie decyzyjnym projektowania urbanistycznego. Posłuży mu do tego celu przykład opracowania miejscowego planu rewitalizacji dla tzw. „Starówki” Miasta Wołomin.

Słowa kluczowe: badanie ankietowe, projektowanie partycypacyjne, przestrzeń, urbanistyka. 


\section{INTRODUCTION}

The concept of the modern process of urban design determines many parallel threads, research planes, which the designer is forced to skillfully combine in order to achieve the intended design goal. Urban design is a topic related to a complex analysis of many areas of the economy gospodarki (Rosiak Ł. 2016). With the passage of time, technical and technological progress, every area of life undergoes transformations, changes corresponding to the present era. Urban designing is based on the effective organization of urban space so as to respond more accurately to the needs of its inhabitants. With this in mind, an urban planner must approach a complex and tedious design process in a multi-criteria approach (Rosiak Ł. 2014, p. 284-293). During inventory, analytical or concept work, it takes into account the changing legal basis (Rosiak Ł. 2018, p. 141-158), takes into account the vicinity of areas that may have an impact on the area covered by its development, it takes into account the geographical factor, natural, ownership, communication links, etc. Before clarifying any design concept, an effort should be made to carry out a series of analyzes: functions and height of buildings, greenery, technical infrastructure, age of buildings, functional and spatial connections or visual valorization of the area. In addition to the aforementioned elements, there are also social factors resulting from legal acts and the adopted course of administrative proceedings or the inclusion of the so-called social participation in the entire process of social participation good practices. The latter are designed to involve the local community in the active process, which will most accurately define its needs. It should be mentioned that the involvement of the local community has changed (Rosiak Ł. 2016, p. 117-129). From experimental novelty to widespread practice, often required by law (Barełkowski R. 2021, p. 77-108). The presence of various groups in the above-described process has become an indispensable element. Space is a common good. Each person, having a specific affiliation in social life, occupies some part of this whole. That is why there are so many dependencies in the processes of spatial interference (Jacobs A., Appleyard D. 1987, s. 112-120). At the same time, the social roles of an individual are the determinant of decisions made (Rosiak Ł. 2020, p. 129-142). In order to obtain more complete information from people emotionally connected with the place, the urban planner also includes in his professional activities those involving, for example, social sciences. One of the research techniques is a questionnaire survey. This research is the simplest form of communicating a lot of information in a simplified way. This research is the basic, quantitative form of communicating a lot of information in a simplified way. It can be traditional or online. It is a research technique to collect information from respondents using a questionnaire and conducting direct interviews with PAPI respondents (Paper and Pencil Interview) or the Internet CAWI (Computer-Assisted Web Interview). An interesting form is a street survey in the Central Location formula. It consists in conducting questionnaire research in key points for a given spatial unit, in busy places where inhabitants naturally gather (communication junctions, squares, squares, promenades, around churches, shops, public institutions). Study participants are detected among passers-by (Suchomska J, Kołacz P. 2016, p. 55 and Hajduk S., 2021, p. 20). An online survey is much cheaper and allows you to reach a much larger audience. The survey lasts from one week to one month, and it takes fifteen to forty-five minutes to complete it. The way to reach users are websites, specially prepared platforms or social networks. When creating a survey, it is important to choose the questions well, because they affect the formulation of the answers. The questionnaire survey consists of successive activities that lead to the general goal of the final results, as illustrated in the diagram 1 below.

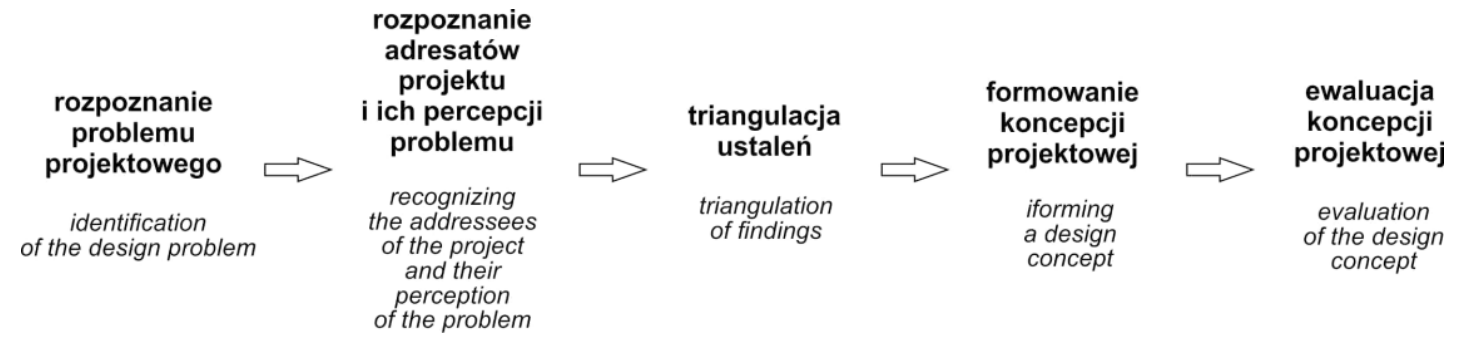

Fig. 1 Diagram showing design activities. Source: own study

Ryc. 1. Schemat obrazujący czynności projektowe. Źródło: opracowanie własne 
The author in this work, on the basis of a two-stage questionnaire, will try to explain the importance of this research technique in the decision-making process of urban design. Making important decisions is associated with the risk of their accuracy. Most often, decisions are made on the basis of collected data from the target groups of the planned solution. The author will use an example for this purpose of developing a local revitalization plan for the so-called "Old Town" of the City of Wołomin made by Armageddon Biuro Projektowe from Poznań. The author had the opportunity to join the project team and in June - October 2021, cooperating with the office, to carry out tasks together. The concept area covers the area limited by the border of the railway tracks of the Warsaw - Białystok line, Przejazd, Wileńska, Legionów streets and a short section of Żelazna Street in Wołomin. This article aims to present how the potential of a survey is used in two different phases of urban design. The first is a questionnaire relating to the existing condition - the diagnosis of the condition. The second study is currently being carried out at the stage of presenting the design concept. This questionnaire is designed to identify social assessments of spatial solutions.

\section{METHOD}

The research presented in this article uses the achievements combining the theoretical foundations of urban planning and design related to participatory forms. Other forms of participation include, among others, the World Café - Youth workshops in the participation laboratory "Rimpiazza": revitalization of Santissima Annunziata Square (Florence) or participation workshops - Revitalization of the area of public space and buildings in the downtown section of Aleja Wojska Polskiego in Szczecin. An in-depth participatory process was carried out during the preparation of MPZP in the city of Trzebinia. Consultation workshops with a model of the area, World Café and an interactive map were used. Social participation is an element that brings project procedures closer to reality. He described their potential tasks (Sanoff $H_{\text {., }} 2000$ ), pointing to the circulation of information about the environment, necessary for a multi-threaded transformation, which should result in the improvement of the conditions for the functioning of the community that the project concerns, without diminishing (or without significantly reducing) depletion) of environmental resources. Since the systematics of participatory forms was developed by (Arnstein S. R. 1969), it became clear that the seed forms, focused solely on information or creating the possibility of expression by participants of project procedures, treat the respondents too instrumentally. Therefore, a number of different methods are used by town planners in a way that, at least intentionally, is to involve respondents to the formulation of relevant initial and evaluation information for the project. These are, for example: a 300-hectare revitalization project designated by the President of the Bronx District in New York (Sanoff H., 2000), Future Scenario Workshops in the Mora Commune (Sweden). These projects look for forms of participation that broaden the range of possibilities of reaching project recipients, as well as obtaining their statements, opinions and evaluations. Thus, the survey seems to be a seemingly little innovative solution, traditionally functioning in the form of predefined queries and, often for ease, closed or semi-closed response formula, e.g. ready-made options to choose from. The survey should be perceived as a fully-fledged participatory form, which, in opposition to many soft techniques of obtaining the respondents' opinions, is definitely more disciplined. First of all, the questionnaire establishes mutual and unified rules for conducting a dialogue between the designer, participant, and the ordering party (very often - the local government representing the community). Establishing a common language is very important. The questionnaire allows you to draw attention to specific, leading issues and, although it takes away some freedom of expression, it nevertheless creates constructs helpful in the implementation of the urban plan: 1) presents the key elements of the dictionary necessary for the effectiveness of the dialogue; 2 ) informs the recipients of the project about what is important for the designers and, most likely, also for the contracting authority, which also makes it possible to find out whether the designer and the contracting authority have correctly identified the problem of the project together. Regardless of the above, the survey organizes and prioritizes opinions - by introducing a normalized scale, which may not fully reflect the nuances of opinions created by respondents, but necessary to build a picture of how the project was received and how individual respondents negotiate the interpretation of their opinion in the imposed scale of ratings. After all, such a scale is necessary for the designer and contracting authority to be able to see the aggregate results in a way that makes each statement equivalent ma- 
terial (otherwise, each statement could be incompatible with another, offering completely different evaluation criteria, a different scale, different nomenclature of the assessed state of the project). Therefore, the following questions can be added to the above-mentioned tasks of the survey: 3 ) standardization of assessments and verdicts issued by respondents; 4) prioritization of individual project features, and hence ratings; and 5) eliminating the contamination of the participatory process through the expression of particular needs, in which the interest of the individual is put before the interest of the community (by imposing questions and problem areas to be assessed; (Barełkowski R. 2021, p. 77-108). Haklay, Jankowski and Zwoliński, who noticed the problem of representativeness, i.e. the participation of all necessary groups of recipients of the project (Haklay M., Jankowski P. and Zwoliński Z. 2018, 127-149). This also corresponds to the comments of Barełkowski, who indicated the selectivity of participation narrowed only to those who decided to participate in it while having to satisfy the needs of all members of the community, the inability to create a fully equivalent position of a designer and recipient of the project due to differences in education, professional matter, and finally the degree of involvement in the implementation of the project (Barełkowski R. 2021, p. 77-108). Similar limitations - particularism and the inability to reflect the full spectrum of representations - were also diagnosed by Hou (Hou 2011, s. 329-340).

In the project discussed in the article, the planning procedure is implemented in a way that treats participation as a fully-fledged element accompanying the entire critical phase of forming a spatial solution. The choice of the questionnaire results from the possibility of showing the design of specific mechanisms and demonstrating the degree of their use in the design concept. It is a more objectified process than in the case of other forms of participation that functioned in the procedure. The tendency to popularize the initiation of social participation, gradually introduced abroad since the 1970s, was perceived at the turn of the century as a perspective for the development of the use of information technology, which prompted attempts to apply it also in Poland (Barełkowski 2001, 111-112). The method used, developed at the end of the 20th century, is the P.R.S. It assumed a three-thread structure of the process, from planning $(P)$, through references - in fact the recognition of the area, its physiography, history, social and cultural conditions (R), etc., to social participation (S) (Barełkowski R., Barełkowska K. 2003 , pp. 7-22). The authors of the study, although aware that the first questionnaire usually "exhausts" the strength and commitment of the local community, nevertheless designed the relationship between the two rounds of sampling public opinion. The state diagnosis questionnaire is part of the diagnosis, a specific inventory of the social and material reality of the area in which the intervention is to be planned. On the other hand, the spatial solutions assessment survey is a necessary feedback, examining how the assumptions of the concept will be adopted by the active part of the inhabitants of the intervention area. This survey is to correct a possible design intent. In this way, designing participation becomes an integral part of designing mechanisms for maintaining the quality of design solutions, it also fulfills the tasks indicated by Giancarlo de Carlo for participation in design - supporting the definition of a design problem, support for the development of a design solution and evaluation of the results of the design process (de Carlo 2011, 753-758).

\section{FIRST STAGE - QUESTIONNAIRE - CONDITION DIAGNOSIS}

The first stage of work on the development of a local revitalization plan for the so-called The "Old Town" of the city of Wołomin was to launch a survey on the diagnosis of the state. This study was carried out in two ways. The internet platform was launched on June 18, 2021 and the questionnaire was disseminated in the traditional printed form. The questionnaire concerning the diagnosis of the state was used to determine the spatial problems occurring in the revitalization area, the most important for the community. This stage is extremely important for designers to make and confront an appropriate diagnosis for the improvement of the studied place with the perception of its existing state by local target groups. At this point, the traditional approach to the design topic cannot be omitted. Designers making a local vision, get acquainted with the topic and inventoried the most important problems of the place in their opinion. By commencing a critical analysis of the area, they score the leading postulates resulting from their own observation. Immediately after these activities, a questionnaire was developed, which was to be used by the designers to verify 
their own observations and find any additional difficulties that could expand the range of those already discovered. At the stage of determining the current state and with reference to diagram no.1, the questionnaire form is included in the entire research process after the activities related to the familiarization with the topic - this is illustrated in diagram no.2.

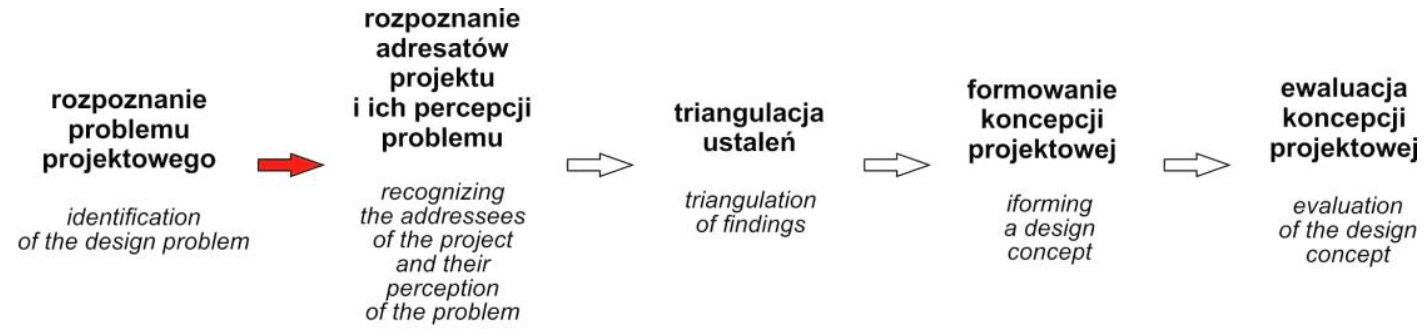

$\Rightarrow$ miejsce włączenia ankiety the place where the questionnaire

Fig. 2. Diagram showing the place where the questionnaire was included in the first stage. Source: own study Ryc. 2. Schemat obrazujący miejsce włączenia ankiety do I etapu. Źródło: opracowanie własne
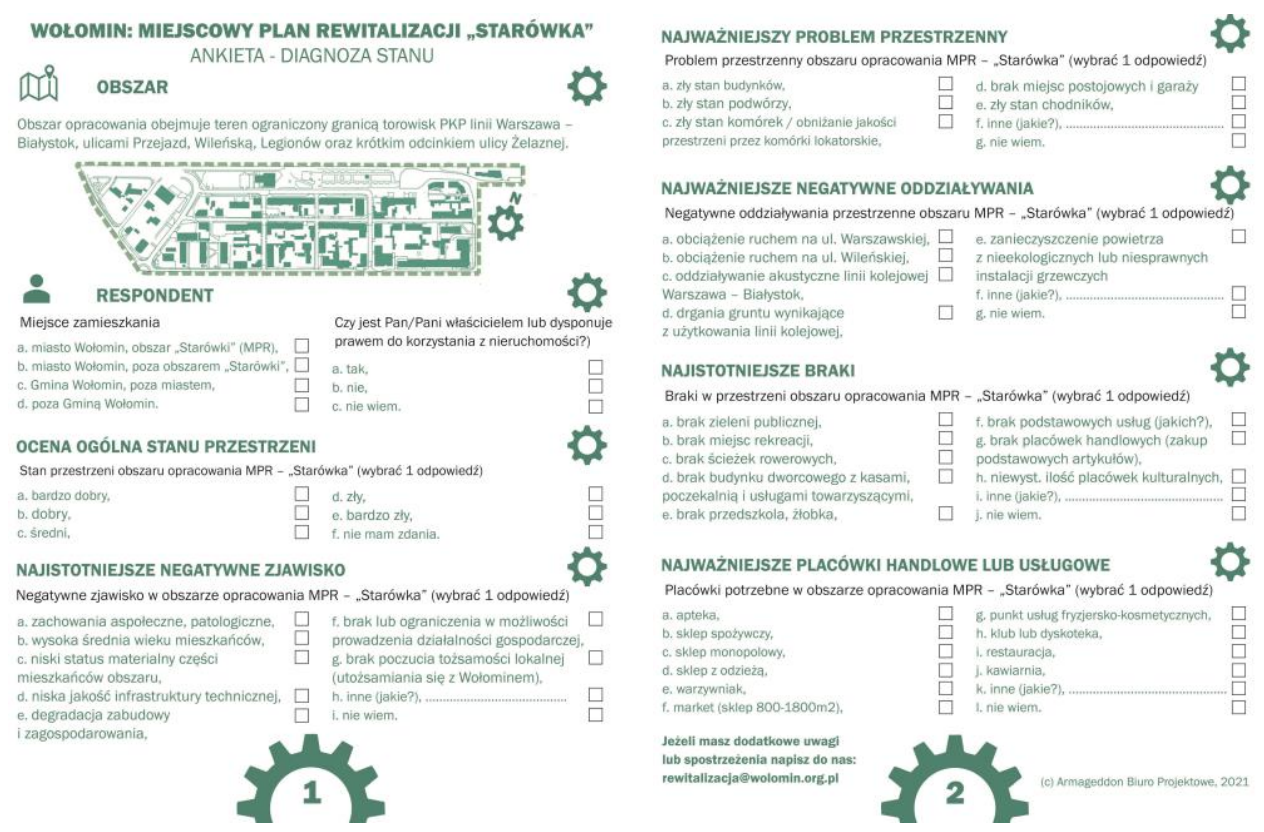

Fig. 3. Questionnaire - condition diagnosis. Source: Description Armageddon Biuro Projektowe

Ryc. 3. Ankieta - diagnoza stanu. Źródło: Opracowanie Armageddon Biuro Projektowe

The point depicted in the diagram shows where the participants are joining the study. This is a key point in the entire exercise. The urban planner dealing with the subject is already after getting acquainted with the subject. Most of the respondents know the area of research, and random people who do not come from the target group also have this step behind them. From the point of view of urban design, the content of the questionnaire (illustration no. 3) diagnosing the current state affects the most important elements of the examined place. ...the reach of public consultations when drawing up draft local plans is negligible. This is due to several reasons: low awareness and knowledge of citizens about spatial planning, lack of development of information and communication means with the society, lack of interest of municipal authorities in the broad participation of society in the creation of local law (Czekiel-Świtalska E. 2012, p. 325- 338). From the above assumption, the questionnaire was to be short with accurate insights to facilitate the choices. The 
time needed for the response was to be kept to a minimum in order to encourage the largest possible target group to participate in the research. A survey itself in order to reach the largest possible audience. It is preceded by the dissemination of folders informing in a simple way about the design intention and the legitimacy of what it serves (Barełkowski R. 2014, p. 25-46).

\section{SECOND STAGE - QUESTIONNAIRE - EVALUATION OF SPATIAL SOLUTIONS}

The second stage of work on the development of a local revitalization plan for the so-called In the "Old Town" of the City of Wołomin, another questionnaire was disseminated on the Internet on November 15, 2021. The form was also available in the traditional print version. The questionnaire from the second stage was to be used to find answers to the proposed design solutions. This comment is also important and constitutes an extremely important response on the part of the respondents in terms of the accuracy and evaluation of the proposed solutions. At this point, the traditional approach to the design topic led by experts cannot be omitted. The results of the preliminary surveys obtained by the designers were confronted with the image of their own vision. After these activities, the design concept was developed. At the same time, the questionnaire form presented in Figure 4 was developed.
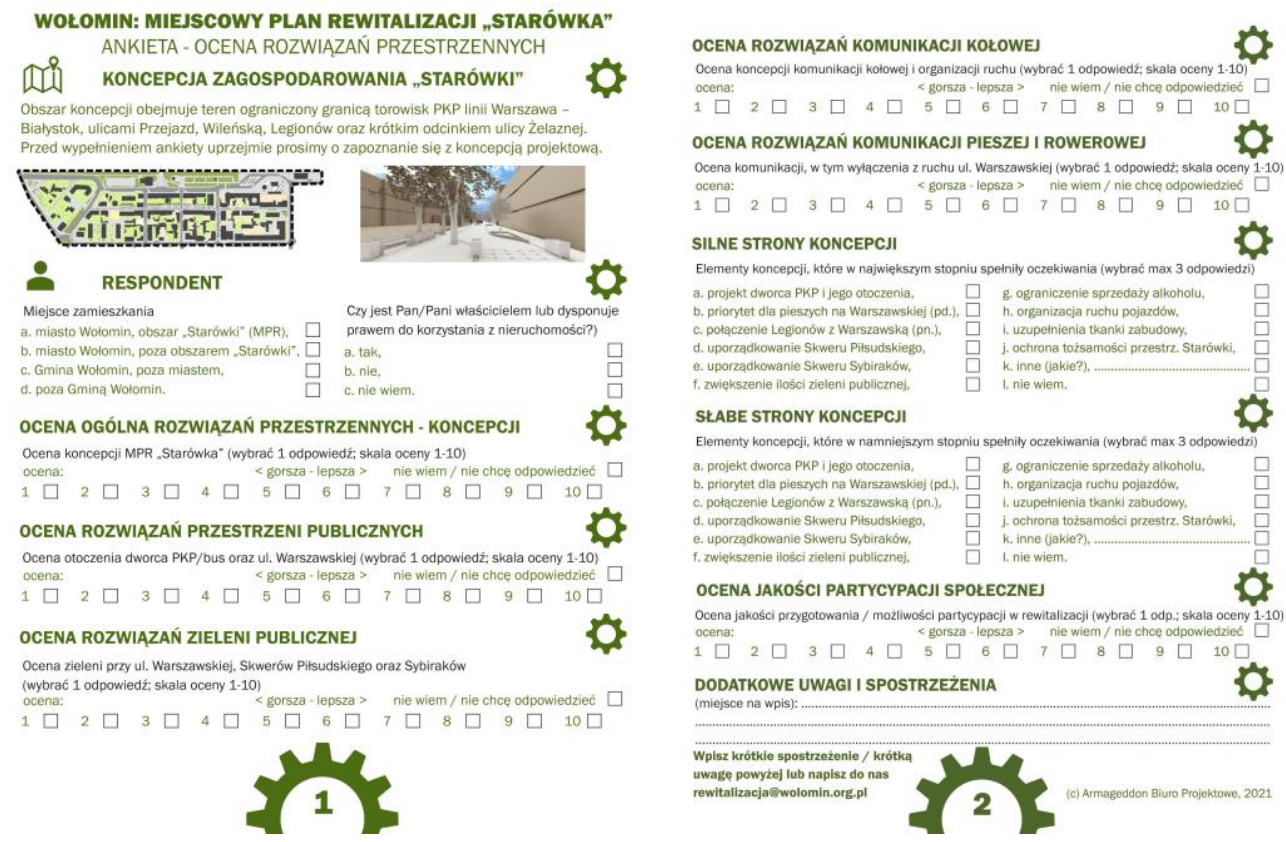

Fig. 4. Questionnaire - evaluation of spatial solutions. Source: Description Armageddon Biuro Projektowe

Ryc. 4. Ankieta - ocena rozwiązań przestrzennych. Źródło: Opracowanie Armageddon Biuro Projektowe

The survey questionnaire was used to evaluate the presented design solutions. During the solution assessment stage the questionnaire form is included in the entire research process only during the relevant activities resulting from the research process - this is illustrated in diagram 5.

As in the case of the survey from the first stage, the content of the survey is now easily accessible in the second stage. Taking into account the general reluctance to pay attention to the lengthy and complex questions of the interviewers, this questionnaire was shaped similar to the one used in the first stage. The questionnaire was to be short with relevant insights to facilitate the choices. A fully completed questionnaire is to evaluate the proposed spatial solutions, return to urban planners and be a signal for them whether the directions of inquiry have been selected correctly. The forms from both stages were constructed in such a way as to enable the respondent to answer in an open form to better understand the local community. Closed questions would lead to the use of an answer 
that is not necessarily truthful, which would significantly undermine the purposefulness of the research, and the results and conclusions drawn on them would be of little use (Szyjewski Z. 2018, p. 147-162).

\begin{tabular}{|c|c|c|c|c|}
\hline $\begin{array}{l}\text { rozpoznanie } \\
\text { problemu }\end{array}$ & $\begin{array}{c}\text { rozpoznanie } \\
\text { adresatów } \\
\text { projektu } \\
\text { i ich percepcji } \\
\text { problemu }\end{array}$ & $\begin{array}{c}\text { triangulacja } \\
\text { ustaleń }\end{array}$ & $\begin{array}{l}\text { formowanie } \\
\text { koncepcji } \\
\text { projektowej }\end{array}$ & $\begin{array}{c}\text { ewaluacja } \\
\text { koncepcji } \\
\text { projektowej }\end{array}$ \\
\hline $\begin{array}{c}\text { identification } \\
\text { of the design problem }\end{array}$ & $\begin{array}{l}\text { recognizing } \\
\text { the addressees } \\
\text { of the project } \\
\text { and their } \\
\text { perception } \\
\text { of the problem }\end{array}$ & $\begin{array}{l}\text { triangulation } \\
\text { of findings }\end{array}$ & $\begin{array}{l}\text { iforming } \\
\text { a design } \\
\text { concept }\end{array}$ & $\begin{array}{l}\text { evaluation } \\
\text { of the design } \\
\text { concept }\end{array}$ \\
\hline
\end{tabular}

$\Rightarrow$ miejsce włączenia ankiety the place where the questionnaire

Fig. 5. Diagram showing the place where the questionnaire was included in the second stage. Source: own study Ryc. 5. Schemat obrazujący miejsce włączenia ankiety do II etapu. Źródło: opracowanie własne

\section{CHANGES GENERATED BY THE "DIAGNOSIS OF STATUS" SURVEY RESULTS}

To solve the problems of the local revitalization plan for the so-called In the "Old Town" of Wołomin, the design team prepared two concepts. Both took into account the residents' postulates resulting from the first survey. In the course of public consultations, far-reaching similarities emerged in the shaping of the elements of the program content aimed at revitalization. The contents are presented in Table 6.

Tab. 6. Summary table of the assumptions of the concept MPR. Source: Description Armageddon Biuro Projektowe

\begin{tabular}{|c|c|c|c|}
\hline & 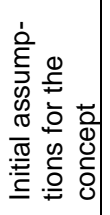 & 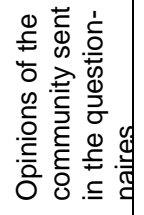 & 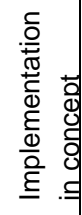 \\
\hline \multicolumn{4}{|l|}{ Basic assumptions of the concept of the Local Revitalization Plan (MRP) } \\
\hline $\begin{array}{l}\text { 1. Establishing the rules and parameters allowing for the gradual ordering of the spatial } \\
\text { structure of urbanized quarters, which should enable the maintenance of the building sub- } \\
\text { stance in good condition as a vital urban tissue filled with a multiple, heterogeneous pro- } \\
\text { gram. }\end{array}$ & yes & yes & yes \\
\hline $\begin{array}{l}\text { 2. Ordering the quarters: } \\
\text { a. preservation of the original, industrial character of stone buildings along with the mainte- } \\
\text { nance of their frontage character, with the admission of modern additions due to the need to } \\
\text { maintain the continuity of structures for centuries, }\end{array}$ & yes & yes & yes \\
\hline $\begin{array}{l}\text { 2. Ordering the quarters: } \\
\text { b. preservation of spatial and urban identity with the admission of modern additions (signum } \\
\text { temporis, avoiding imitation activities, contrary to the principles of the protection of architec- } \\
\text { tural and urban heritage, but in harmony and in harmony - ICOMOS principles), }\end{array}$ & yes & - & yes \\
\hline $\begin{array}{l}\text { 2. Ordering the quarters: } \\
\text { c. indications for preserving the elements of the original yard management (tenant cells) as } \\
\text { "witnesses" - point-by-point, as well as the process of eliminating substandard cells. realized } \\
\text { accidentally or significantly deprived of capital, }\end{array}$ & yes & yes & yes \\
\hline $\begin{array}{l}\text { 2. Ordering the quarters: } \\
\text { d. improvement of the technical condition without architectural deformation of structures, }\end{array}$ & yes & - & yes \\
\hline 2. Ordering the quarters: & yes & - & yes \\
\hline
\end{tabular}




\begin{tabular}{|c|c|c|c|}
\hline $\begin{array}{l}\text { e. preserving the possibility of coexistence of the original single-family housing with multi- } \\
\text { family housing, and in selected places of introducing new multi-family housing. }\end{array}$ & & & \\
\hline $\begin{array}{l}\text { 3. Building functional routes along Warszawska Street (central part; proposed as Henryka } \\
\text { Wojciechowskiego Street), and along Żelazna and Warszawska Streets (northern part). }\end{array}$ & yes & - & yes \\
\hline $\begin{array}{l}\text { 4. Significant improvement in pedestrian and communication access, as well as supplement- } \\
\text { ing the structure of bicycle routes. }\end{array}$ & yes & - & yes \\
\hline $\begin{array}{l}\text { 6. Remodeling the surroundings of the railway station and the bus station in order to create } \\
\text { an integration, accommodation and representative space in such an important place. }\end{array}$ & yes & yes & yes \\
\hline 7. Corrections of pedestrian routes and their integration with functional routes. & yes & - & yes \\
\hline $\begin{array}{l}\text { 8. Reorganization of road traffic with the transfer of traffic circumferentially in relation to the } \\
\text { housing tissue (including improvement of the safety of the road system). }\end{array}$ & yes & yes & yes \\
\hline \multicolumn{4}{|l|}{ Supplementary assumptions indicated in the participation process } \\
\hline Increasing the share of greenery inside the revitalization area & - & yes & * \\
\hline Setting standards for heating installations (elimination or reduction of emissions) & - & yes & * \\
\hline Improving the quality of infrastructure (mainly rainwater drainage) & - & yes & * \\
\hline Necessity to complete the system of bicycle paths (connections) & - & yes & * \\
\hline Elimination of liquor stores & - & yes & * \\
\hline $\begin{array}{l}\text { The need to increase the number of service establishments, especially catering (re-creation } \\
\text { of services and trade with the support of local administration - discounts, etc.) }\end{array}$ & - & yes & * \\
\hline Elimination or significant reduction of car traffic in Warszawska Street (central part) & - & - & * \\
\hline
\end{tabular}

* Supplementary assumptions indicated in the participation process in the current phase are under development. Evaluation of the MPR concept in progress.

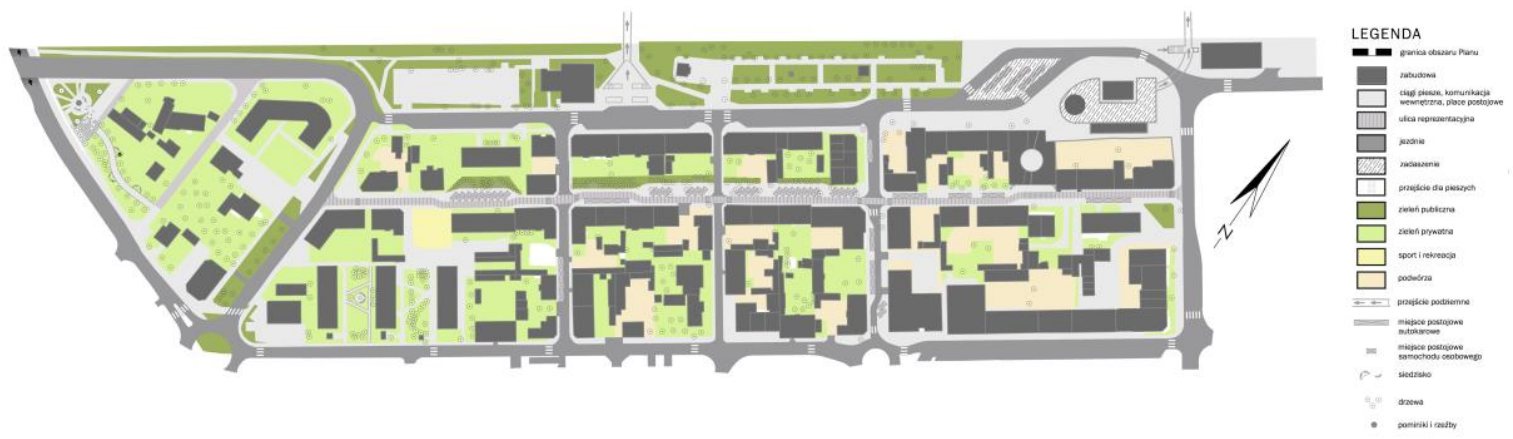

Fig. 7. Development concept - version no. 2. Source: Description Armageddon Biuro Projektowe Ryc. 7. Koncepcja zagospodarowania - wersja nr 2. Źródło: Opracowanie Armageddon Biuro Projektowe

\section{CONCLUSIONS - SUMMARY}

Restrictions resulting from the ownership right, complications resulting from spatial limitations and the involvement of local government in already implemented or completed projects that were not previously correlated with the revitalization process, significantly change the degree of effectiveness of translating the results of the survey into a concept (cf. Tormenta Pinto 2013, 1449- 1450). This does not make the survey any less important, but remains fully equal. The introduction of the 
questionnaire to these two stages in the case under consideration is an aid in the implementation of the urban plan and allows to draw attention to the leading problem issues in terms of which the social awareness of the conditions accompanying design decisions is generated. This means that the community knows not only about the project, but its causes and justification for its shape. The role of the survey in urban design is manifold, which can be stated considering the way in which it functioned in the "Old Town" project in Wołomin: 1. The questionnaire introduces to the common use (at least the local community) the conceptual system necessary to conduct a discourse on design topics, systematizes other nomenclature elements, of course not in the strict sense - in logical terms - but sufficiently directing the absorption of the definition, that most of the issues discussed in the discourse were communicative to recipients unfamiliar with the disciplinary language of architecture. 2. To be effective, the questionnaire must have a relatively laconic form, convenient for the respondent to complete. That means it can't be too long. Brevity, therefore, requires us to weigh our words and limit the questions to the most essential ones. The respondent stands in front of the distilled material, drawing his attention to what, according to the contracting authority and the designer, is the most important - and he relates to it. On this basis, it can be concluded that the informative role of the survey, focused on examining the need for intervention and its desired forms (Rosiak Ł. 2016, pp. 41-55), is supplemented by other forms of participation, better in obtaining free comments, ideas and observations on undefined by the designer. Naturally, one can imagine the components of the survey in the form of semi-open questions (in which the respondent can add his own comments), but in the case of the survey it is an ineffective formula, because it is not very coherent with the main form of answering the survey questions - concrete, segregated, disambiguating even then, when the individual answers do not fully reflect the respondent's intentions. 3 . The questionnaire does not act as the only element of the information policy and the basis responsible for creating the image of the project and the context of this project (its meanings, factors influencing its formation, which the respondents may not be aware of). Nevertheless, the survey makes it possible to construct and possibly correct the hierarchy of importance of the tasks that the designers are to deal with. 4. For the designer, but also other participants of the decision-making process, it is important to determine how the hierarchy of criteria for evaluating the design solution proposed by the designer to the participants should change before it becomes the basis for making irreversible architectural or urban decisions. Therefore, it is necessary to calibrate the assessments issued by the project recipients and, consequently, to standardize the survey results (as mentioned in point 3 above). This calibration takes place in particular through the second questionnaire, because the first one is the recognition of the hierarchy of problems as the respondents see them. These considerations can be summarized in such a way that the designer recognizes the hierarchy of problems, then proposes a hierarchy of remedies, translates them into a material, spatial form supplemented optionally with legal regulations, and returns the hierarchy of program-spatial components. The respondents react to this hierarchy (in the evaluation questionnaire), allowing it to be calibrated, changed, adapted - in the end, a concept is formed that reflects the synergy of the idea of the designer and the needs of recipients to the greatest possible extent. This is how you get to point 5 , indicated below. 5. The questionnaire through an individual refers to the needs of the community with a view to the benefits for the own environment. Knowledge of various research methods and techniques plays an important role in contemporary urban design that uses social participation and a broader consultative participation. Design offices carry out various activities using the potential hidden in the method and implement it to work in making decisions. As noted by Henry Sanoff, it was necessary to socialize architecture in order to: serve the needs that are often ignored by organizations, bureaucratic institutions and "experts" dealing with planning and design. Summarizing the material collected and described in individual chapters, it can be concluded that the questionnaire is one of the simplest forms of obtaining information. Such research allows for reaching a fairly large representative group through additional methods, e.g. the snowball method. Wellchosen questions will result in accurate answers and a more complete understanding of the subject the respondent is asked about. The simpler the questions are formulated, the simpler and more accurate answers can be expected. There are also many shortcomings of this technique. One of them is that the results are not guaranteed to be reliable. The respondent may transfer his current emotional state to the questionnaire, which does not reflect his real emotions in relation to the content of the questionnaire (Szyjewski Z. 2018, p. 147-162). From the conducted research on the use 
of a two-stage questionnaire in the process of urban design, conclusions can be drawn that can be described as positive and negative. In the so far presented fragment of the entire design process, this study can be considered as an element that complements the designers' insights. The general factor of any research is the need for knowledge. In addition to the methods used to shape the environment so far, town planners will use the knowledge of other users of this process (Rosiak $k$. 2018 , s. 33-48). Based on the knowledge obtained from the recipients, they will create projects based not only on spatial possibilities supported by hope for acceptance, but implemented in a form accepted by the majority of stakeholders (Rosiak Ł. 2014, p. 38-45).

You can also notice a very important difference in the place where the survey is included in the whole process. In the first stage, the questionnaire is included in the initial steps. The second stage is the final steps. Both the moment of starting the survey are correct. It all depends on the content of the survey to be enabled. Its content must be adequate to the examined point from the entire process.

\section{ROLA ANKIETY DWUETAPOWEJ W PROCESIE PROJEKTOWANIA URBANISTYCZNEGO}

\section{WPROWADZENIE}

Pojęcie jakim jest współczesny proces projektowania urbanistycznego determinuje w sobie bardzo wiele równolegle występujących wątków, płaszczyzn badawczych, które projektant zmuszony jest umiejętnie łączyć, aby osiągnąć zamierzony cel projektowy. Projektowanie urbanistyczne to tematyka związana ze złożoną analizą wielu obszarów gospodarki (Rosiak Ł. 2016). Wraz z upływem czasu, postępem technicznym, technologicznym, każda dziedzina życia ulega przeobrażeniom, zmianom odpowiadającym obecnej epoce. Projektowanie urbanistyczne polega na efektywnym organizowaniu przestrzeni miejskiej, tak aby trafniej odpowiadać na potrzeby mieszkańców (Rosiak Ł. 2014, s. 284-293). Mając to na uwadze, urbanista musi podejść wielokryterialnie do złożonego i żmudnego procesu projektowego. Podczas prac inwentaryzacyjnych, analitycznych czy opracowania koncepcji uwzględnia on zmieniające się podstawy prawne (Rosiak $Ł$. 2018, s. 141-158), bierze pod uwagę sąsiedztwo obszarów, które mogą wywrzeć wpływ na obszar objęty jego opracowaniem, ma na względzie czynnik geograficzny, przyrodniczy, własnościowy, powiązań komunikacyjnych etc. Przed wyklarowaniem jakiekolwiek koncepcji projektowej należy podjąć się wysiłku wykonania szeregu analiz: funkcji i wysokości zabudowy, zieleni, infrastruktury technicznej, wieku zabudowy, powiązań funkcjonalno-przestrzennych czy waloryzacji wizualnej terenu. Oprócz tych wspomnianych elementów dochodzą czynniki społeczne wynikające z aktów prawnych oraz przyjętego toku postępowania administracyjnego czy włączenie w cały proces partycypacji społecznej tzw. dobrych praktyk. Te ostatnie mają za zadanie włączyć w czynny proces lokalną społeczność, która najtrafniej określi swoje potrzeby. Należy nadmienić, że zmieniło się zaangażowanie lokalnej społeczności (Rosiak Ł. 2016, s. 117-129). Z eksperymentalnej nowości w szeroko rozpowszechnioną praktykę, często wymaganą przepisami prawa (Barełkowski R. 2021, s. 77-108). Obecność różnych grup w wyżej opisanym procesie stała się elementem nieodzownym (Jacobs A., Appleyard D. 1987, 112-120). Przestrzeń jest dobrem wspólnym. Każdy człowiek, mając określoną przynależność w życiu społecznym, zajmuje jakiś wycinek tej całości. Dlatego też w procesach ingerencji przestrzennych występuje tak wiele zależności. Jednocześnie role społeczne jednostki są wyznacznikiem podejmowanych decyzji (Rosiak Ł. 2020, s. 129-142). W celu pozyskania pełniejszej informacji od osób emocjonalnie związanych z miejscem urbanista włącza do zawodowych działań także te, polegające na np. naukach społecznych. Jedną z technik badawczych jest badanie ankietowe. Badanie to jest podstawową, ilościową formą zakomunikowania wielu informacji w uproszczony sposób. Może być tradycyjne lub internetowe. Jest to technika badawcza do zbierania informacji od respondentów wykorzystująca kwestionariusz i prowadzenie bezpośredniego wywiadu 
z respondentami PAPI (ang. Paper and Pencil Interview) lub internetu CAWI (ang. ComputerAssisted Web Interview). Interesującą formą jest sondaż uliczny w formule Central Location. Polega on na prowadzeniu badań ankietowych w punktach kluczowych dla danej jednostki przestrzennej, miejscach ruchliwych, w których naturalnie gromadzą się mieszkańcy (węzły komunikacyjne, place, skwery, deptaki, okolice kościołów, sklepów, instytucji publicznych). Uczestników badania wychwytuje się wśród przechodniów (Suchomska J, Kołacz P. 2016, s. 55 i Hajduk S. 2021, s. 20). Ankieta internetowa jest znacznie tańsza i pozwala dotrzeć do znacznie większej liczby odbiorców. Czas trwania ankiety to od tygodnia do miesiąca, jej wypełnienie trwa od piętnastu do czterdziestu pięciu minut. Sposobem na dotarcie do użytkowników są strony internetowe, specjalnie przygotowane do tego platformy lub sieci społecznościowe. Przy tworzeniu ankiety ważne jest dobre dobranie pytań, gdyż wpływają one na formułowanie odpowiedzi. Badanie ankietowe składa się z następujących po sobie czynności, które prowadzą do ogólnego celu - wyników końcowych, ilustruje to poniższy schemat nr 1.

Autor w niniejszej pracy na podstawie ankiety dwuetapowej będzie się starał wyjaśnić jakie jest znaczenie tej techniki badawczej w procesie decyzyjnym projektowania urbanistycznego. Podejmowanie ważnych decyzji związane jest z ryzykiem ich trafności. Najczęściej decyzje podejmowane są na podstawie zebranych danych od grup docelowych planowanego rozwiązania. Autorowi posłuży do tego celu przykład opracowania miejscowego planu rewitalizacji dla tzw. „Starówki” Miasta Wołomin wykonanego przez Armageddon Biuro Projektowe z Poznania1. Autor miał okazję dołączyć do zespołu projektowego i w miesiącach czerwiec - październik 2021 r. współpracując z biurem realizować wspólnie zadania. Obszar koncepcji obejmuje teren ograniczony granicą torowisk PKP linii Warszawa - Białystok, ulicami Przejazd, Wileńską, Legionów oraz krótkim odcinkiem ulicy Żelaznej w Wołominie.

Niniejszy artykuł ma na celu zaprezentować w jaki sposób wykorzystywany jest potencjał badania ankietowego $w$ dwóch różnych fazach projektowania urbanistycznego. Pierwszą z nich jest ankieta odnosząca się do istniejącego stanu - diagnoza stanu. Drugie badanie realizowane jest obecnie, na etapie prezentacji koncepcji projektowej. Ankieta ta ma za zadanie rozpoznać społeczne oceny rozwiązań przestrzennych.

\section{METODA}

W dociekaniach prezentowanych w niniejszym artykule wykorzystano dorobek łączący teoretyczne podstawy planowania i projektowania urbanistycznego powiązane $z$ formami partycypacyjnymi. Innymi formami partycypacji są między innymi np. warsztaty World Café - Młodzież w laboratorium partycypacji „Rimpiazza”: rewitalizacja Placu Santissima Annunziata (Florencja) lub warsztaty partycypacyjne - rewitalizacja obszaru przestrzeni publicznej i zabudowy śródmiejskiego odcinka Alei Wojska Polskiego w Szczecinie. Pogłębiony proces partycypacyjny prowadzono podczas sporządzania MPZP na terenie miasta Trzebinia. Wykorzystano warsztaty konsultacyjne $z$ makietą terenu, World Café i mapę interaktywną.

Partycypacja społeczna jest elementem, który przybliża procedury projektowe do rzeczywistości. Ich potencjalne zadania opisał (Sanoff H., 2000) wskazując na cyrkulację informacji o środowisku, konieczną dla wielowątkowej transformacji, która powinna przecież zakończyć się poprawą warunków funkcjonowania społeczności, jakiej projekt dotyczy, bez uszczuplania (lub bez znaczącego uszczuplania) zasobów środowiskowych. Od czasu opracowania systematyki form partycypacyjnych przez (Arnstein S. R. 1969) jasne stało się, że formy zalążkowe, skupione wyłącznie na informacji lub tworzeniu możliwości wypowiedzi przez uczestników procedur projektowych zbyt instrumentalnie traktują respondentów. Dlatego szereg rozmaitych metod użytkowanych jest przez urbanistów w sposób, który przynajmniej intencjonalnie angażować ma respondentów do sformułowania istotnych informacji początkowych i ocennych dla projektu. Są to na przykład: 300hektarowy projekt rewitalizacji wyznaczony przez Prezydent Okręgu Bronx w Nowyn Yorku (Sanoff

\footnotetext{
${ }_{1}^{1}$ Armageddon Biuro Projektowe - w skład zespołu wchodzą: generalny projektant - Robert Barełkowski, prof. ZUT dr hab. inż. arch., członek PAN Poznań, WOIA, SARP, ICOMOS PL oraz pozostali członkowie zespołu: Łukasz Wardęski, Mariusz Roszyk, Łukasz Rosiak, Alicja Barełkowska.
} 
H., 2000), warsztaty przyszłościowe (Future Scenario Workshops) w gminie Mora (Szwecja). W projektach tych poszukuje się form partycypacji poszerzających paletę możliwości docierania do odbiorców projektu, a także pozyskiwania ich wypowiedzi, opinii, ocen. Ankieta wydaje się zatem rozwiązaniem pozornie mało innowacyjnym, tradycyjnie funkcjonującym w postaci predefiniowanych zapytań i, często dla ułatwienia, zamkniętej lub półzamkniętej formuły odpowiedzi, czyli gotowych opcji do wyboru.

Ankietę należy postrzegać jako pełnoprawną formę partycypacyjną, która, w opozycji do wielu miękkich technik pozyskiwania opinii respondentów, jest zdecydowanie bardziej zdyscyplinowana. Przede wszystkim ankieta ustala wzajemne i ujednolicone reguły prowadzenia dialogu między projektantem, partycypantem, a zamawiającym projekt (bardzo często - samorządem lokalnym reprezentującym społeczność). Ustalenie wspólnego języka jest bardzo ważne. Ankieta pozwala zwrócić uwage na konkretne, wiodące zagadnienia i wprawdzie odbiera nieco swobodzie wypowiedzi, to jednak tworzy konstrukty pomocne w realizacji zamierzenia urbanistycznego: 1) przedstawia kluczowe elementy słownika koniecznego dla skuteczności prowadzonego dialogu; 2) informuje odbiorców projektu o tym, co jest ważne dla projektantów i najpewniej także zamawiającego, co pozwala również zorientować się, czy projektant i zamawiający wspólnie, prawidłowo, określili meritum problemowe projektu. Niezależnie od powyższego ankieta porządkuje, hierarchizuje opinie przez wprowadzenie znormalizowanej skali, nie oddającej może pełni niuansów opinii tworzonych przez respondentów, ale koniecznej dla zbudowania obrazu, w jaki sposób projekt został odebrany i jak poszczególni respondenci negocjują interpretację własnej opinii w narzuconej skali ocen. Skala taka konieczna jest przecież, by projektant i zamawiający mogli zobaczyć wyniki zbiorcze w sposób czyniący z poszczególnych wypowiedzi materiał ekwiwalentny (inaczej każda wypowiedź mogłaby nie przystawać do innej, oferując zupełnie inne kryteria ocenne, inną skalę, inne nazewnictwo ocenianego stanu projektu). Do wymienionych powyżej zadań ankiety można zatem dopisać: 3) standaryzację ocen i werdyktu wydawanego przez respondentów; 4) hierarchizację poszczególnych cech projektu, a co za tym idzie ocen; a także 5) eliminację skażenia procesu partycypacyjnego przez ekspresję partykularnych potrzeb, w których interes jednostki jest stawiany przed interesem zbiorowości (dzięki narzuceniu pytań i obszarów problemowych do oceny; (Barełkowski R. 2021, s. 77-108). Jest to zatem częściowa odpowiedź na problemy diagnozowane w partycypacji przez Haklaya, Jankowskiego i Zwolińskiego, którzy zauważyli problem reprezentatywności, a więc uczestniczenia wszystkich niezbędnych grup odbiorców projektu (Haklay M., Jankowski P. i Zwoliński Z. 2018, 127-149). Odpowiada to też na uwagi Barełkowskiego, który wskazał wybiórczość partycypacji zawężoną tylko do tych, którzy w niej zdecydowali się brać udział przy konieczności zaspokojenia potrzeb wszystkich członków społeczności, brak możliwości wytworzenia w pełni ekwiwaletnej pozycji projektanta i odbiorcy projektu ze względu na różnice wykształcenia, operowania materią zawodową, wreszcie stopnia zaangażowania w realizację projektu (Barełkowski $R$. 2021, s. 77-108). Podobne ograniczenia - partykularyzm i niezdolność do odzwierciedlenia pełnego spektrum reprezentacji - zdiagnozował także Hou (Hou 2011, 329-340).

W omawianym w artykule projekcie procedura planistyczna realizowana jest w sposób, który traktuje partycypację jako pełnoprawny element towarzyszący całej newralgicznej fazie formowania rozwiązania przestrzennego. Wybór ankiety wynika z możliwości pokazania projektowania określonych mechanizmów i wykazania stopnia ich wykorzystania w koncepcji projektowej. Jest to bardzo zobiektywizowany proces, aniżeli w przypadku innych form partycypacyjnych, które funkcjonowały w procedurze. Tendencje popularyzacji inicjowania społecznej partycypacji, wprowadzanej sukcesywnie zagranica już od lat 70 . XX wieku, postrzegano na przełomie wieków jako perspektywę rozwoju zastosowania technik informatycznych, co skłaniało do podejmowania prób jej aplikowania także w Polsce (Barełkowski 2001, 111-112). Zastosowana metoda P.R.S. zakładała trójwątkową strukture procesu, od planowania $(P)$, przez referencje $-w$ istocie rozpoznanie terenu, jego fizjografii, historii, uwarunkowań społecznych i kulturowych itp., po partycypację społeczną (S) (Barełkowski R. Barełkowska K. 2003, s. 7-22). Autorzy opracowania, świadomi wprawdzie tego, że pierwsza ankieta przeważnie „wyczerpuje” siły i zaangażowanie lokalnej społeczności, mimo wszystko zaprojektowali relację między dwiema turami próbkowania opinii społecznej. Ankieta diagnozy stanu jest częścią rozpoznania, swoistej inwentaryzacji rzeczywistości społecznej i materialnej obszaru, w którym projektowana ma być ingerencja. Natomiast ankieta oceny rozwiązań 
przestrzennych jest konieczną reakcją zwrotną, zbadaniem, jak założenia koncepcji przyjęte będą przez aktywną część mieszkańców obszaru interwencji. Ta ankieta ma korygować ewentualne zamierzenie projektowe. W taki sposób projektowanie partycypacji staje się integralną częścią projektowania mechanizmów zachowywania jakości rozstrzygnięć projektowych, spełnia też zadania, które dla partycypacji w projektowaniu wskazał Giancarlo de Carlo - wspomaganie definiowania problemu projektowego, wsparcie dla opracowywania rozwiązania projektowego oraz ocena rezultatów procesu projektowego (de Carlo 2011, 753-758).

\section{PIERWSZY ETAP - ANKIETA - DIAGNOZA STANU}

Pierwszym etapem pracy nad opracowaniem miejscowego planu rewitalizacji dla tzw. „Starówki” Miasta Wołomin było uruchomienie ankiety dotyczącej diagnozy stanu. Badanie to przeprowadzono dwutorowo. Uruchomiono platformę internetowa w dniu 18 czerwca $2021 \mathrm{r}^{2}{ }^{2}$ oraz rozpowszechniono ankietę $w$ tradycyjnej drukowanej formie. Ankieta dotycząca diagnozy stanu służyła do określenia problemów przestrzennych występujących na obszarze rewitalizacji, najistotniejszych dla społeczności. Etap ten jest niezwykle ważny dla projektantów aby postawić i skonfrontować odpowiednią diagnozę do poprawy badanego miejsca z postrzeganiem jego istniejącego stanu przez lokalne grupy docelowe. W punkcie tym jednocześnie nie można pominąc tradycyjnego podejścia do tematu projektowego. Projektanci dokonując wizji lokalnej, zapoznają się z tematem i wynotowują najważniejsze ich zdaniem problemy miejsca. Przystępując do krytycznej analizy obszaru punktują tym samym wiodące postulaty wynikające z obserwacji własnej. Niezwłocznie po tych czynnościach przystapiono do opracowania kwestionariusza ankiety, który posłużyć miał projektantom do weryfikacji własnych spostrzeżeń i znalezienia ewentualnych dodatkowych trudności, które mogłyby poszerzyć wachlarz tych już odkrytych. Na etapie określania stanu istniejącego formularz ankiety, włączony zostaje w cały proces badawczy po czynnościach związanych z zapoznaniem się $\mathrm{z}$ tematem - obrazuje to schemat $\mathrm{nr} 2$.

Punkt zobrazowany na schemacie pokazuje, w którym momencie do badania włączają się uczestnicy. Jest to kluczowy punkt w całym zadaniu. Urbanista zajmujący się tematyką jest już po czynności zapoznania się z tematem. Respondentom, w większości, obszar badań jest znany, a osoby przypadkowe, nie pochodzące z grupy docelowej, mają także ten krok za sobą.

$Z$ punktu projektowania urbanistycznego treść ankiety (ilustracja $\mathrm{nr} 3$ ) diagnozującej stan istniejący dotyka najistotniejszych elementów badanego miejsca. ...zasięg konsultacji społecznych przy sporządzaniu projektów miejscowych planów jest znikomy. Wynika to z kilku przyczyn: małej świadomości i wiedzy obywateli o planowaniu przestrzennym, braku rozwijania środków informacji i komunikacji ze społeczeństwem, braku zainteresowania władz gmin w szerokim uczestnictwie społeczeństwa w tworzeniu prawa miejscowego (Czekiel-Świtalska E. 2012, s. 325-338). Z powyższego założenia kwestionariusz miał być krótki z trafnymi spostrzeżeniami ułatwiającymi wybory. Czas potrzebny na odpowiedź ograniczyć miał się do minimum, aby zachęcić do badania jak największa grupę docelową. Samo badanie ankietowe, aby dotrzeć do możliwie szerokiego grona odbiorców. Poprzedzone jest rozpowszechnieniem folderów informujących w prosty sposób o zamierzeniu projektowym oraz zasadności czemu ono służy (Barełkowski R. 2014, s. 25-46).

\section{DRUGI ETAP - ANKIETA - OCENA ROZWIAZZAŃ PRZESTRZENNYCH}

Drugim etapem prac nad opracowaniem miejscowego planu rewitalizacji dla tzw. „Starówki” Miasta Wołomin było rozpowszechnienie kolejnego kwestionariusza ankiety $w$ formie internetowej $w$ dniu 15 listopada 2021 r. $^{3}$ Blankiet dostępny był także w wersji tradycyjnego wydruku. Ankieta z drugiego etapu posłużyć miała do odnalezienia odpowiedzi na propozycje rozwiązań projektowych. Kom-

\footnotetext{
2 Ankieta w wersji internetowej dostępna na stronie Urzędu Miasta Wołomin lub poprzez platformę ankietaplus https://ankietaplus.pl/s/45821HAD

3 Ankieta w wersji internetowej dostępna na stronie Urzędu Miasta Wołomin lub poprzez platforme ankietaplus https://ankietaplus.pl/s/60667HNK W ankiecie w wersji cyfrowej doszły dodatkowe pytania o płeć i przedział wiekowy respondenta.
} 
ponent ten jest również ważny i stanowi niezwykle istotną odpowiedź, ze strony respondentów, pod kątem trafności i oceny zaproponowanych rozwiązań.

W tym punkcie nie można pominąć także tradycyjnego podejścia do tematu projektowego prowadzonego przez fachowców. Pozyskane przez projektantów wyniki ankiet wstępnych skonfrontowano z obrazem wizji własnej. Po tych czynnościach przystąpiono do opracowania koncepcji projektowej. Równolegle opracowywano formularz ankiety, który prezentuje ilustracja $\mathrm{nr} 4$.

Kwestionariuszem posłużono się do oceny prezentowanych rozwiązań projektowych. W trakcie etapu oceny rozwiązań 1 formularz ankiety, włączony zostaje w cały proces badawczy dopiero podczas właściwych czynności wynikających z procesu badawczego - obrazuje to schemat nr 5 .

Podobnie jak w przypadku ankiety z pierwszego etapu tak i teraz przy drugim treść ankiety jest przystępna. Mając na względzie powszechną niechęć do poświęcania uwagi na obszerne i skomplikowanie pytania ankieterów ten kwestionariusz ukształtowano podobnie do występującego w pierwszym etapie. Kwestionariusz miał być krótki z trafnymi spostrzeżeniami ułatwiającymi wybory. W pełni wypełniony kwestionariusz ma ocenić zaproponowane rozwiązania przestrzenne, trafić zwrotnie do urbanistów i być dla nich sygnałem czy kierunki dociekań zostały wybrane poprawnie. Blankiety $z$ obu etapów skonstruowano $w$ taki sposób by umożliwić respondentowi odpowiedź $w$ formie otwartej aby pełniej zrozumieć lokalną społeczność. Pytania tylko w formie zamkniętej doprowadziłyby do użycia odpowiedzi niekoniecznie zgodnej z prawdą, co w dużym stopniu podważyłoby celowość badań, a wyniki i na ich podstawie wyciągnięte wnioski miałby niską przydatność (Szyjewski Z. 2018, s. 147-162).

\section{ZMIANY WYGENEROWANE WSKUTEK PRZEPROWADZENIA ANKIETY DIAGNOZY STANU}

Na rozwiązanie problemów miejscowego planu rewitalizacji dla tzw. „Starówki” Miasta Wołomin zespół projektowy przygotował dwie koncepcje. Obie uwzględniały postulaty mieszkańców będące wynikami pierwszej ankiety. W toku konsultacji społecznych ujawniły się daleko idące podobieństwa w ukształtowaniu elementów treści programowych zmierzających do rewitalizacji. Treści pokazuje tabela nr 6.

Tab. 6. Tabela zbiorcza założeń koncepcji MPR. Źródło: Opracowanie Armageddon Biuro Projektowe

\begin{tabular}{|c|c|c|c|}
\hline & 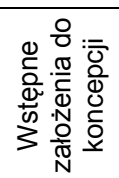 & 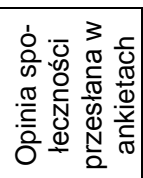 & 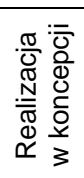 \\
\hline \multicolumn{4}{|c|}{ Zasadnicze założenia koncepcji Miejscowego Planu Rewitalizacji (MRP) } \\
\hline $\begin{array}{l}\text { 1. Ustalenie reguł i parametrów pozwalających na stopniowe porządkowanie struktury } \\
\text { przestrzennej kwartałów zurbanizowanych, które powinny umożliwić utrzymanie sub- } \\
\text { stancji budowlanej w dobrej kondycji, jako żywotnej tkanki miejskiej wypełnionej wielo- } \\
\text { rakim, heterogenicznym programem. }\end{array}$ & tak & tak & tak \\
\hline $\begin{array}{l}\text { 2. Uporządkowanie kwartałów: } \\
\text { a. zachowanie pierwotnego, industrialnego charakteru zabudowy kamienicznej wraz z } \\
\text { utrzymaniem ich pierzejowego charakteru, z dopuszczeniem współczesnych uzupeł- } \\
\text { nień ze względu na konieczność utrzymania ciągłości struktur przez wieki, }\end{array}$ & tak & tak & tak \\
\hline $\begin{array}{l}\text { 2. Uporządkowanie kwartałów: } \\
\text { b. zachowanie tożsamości przestrzennej - urbanistycznej z dopuszczeniem współcze- } \\
\text { snych uzupełnień (zapis signum temporis, unikanie działań imitacyjnych, sprzecznych z } \\
\text { zasadami ochrony dziedzictwa architektonicznego i urbanistycznego, lecz w harmonii i } \\
\text { współbrzmieniu - zasady ICOMOS), }\end{array}$ & tak & - & tak \\
\hline $\begin{array}{l}\text { 2. Uporządkowanie kwartałów: } \\
\text { c. wskazania dla zachowywania elementów oryginalnego zagospodarowania podwórzy } \\
\text { (komórki lokatorskie) jako „świadków” - punktowo, a także proces eliminowania komó- } \\
\text { rek substandardowych. zrealizowanych przypadkowo lub istotnie zdekapitalizowanych, }\end{array}$ & tak & tak & tak \\
\hline
\end{tabular}




\begin{tabular}{|c|c|c|c|}
\hline $\begin{array}{l}\text { 2. Uporządkowanie kwartałów: } \\
\text { d. poprawa stanu technicznego bez deformacji architektonicznej obiektów, }\end{array}$ & tak & - & tak \\
\hline $\begin{array}{l}\text { 2. Uporządkowanie kwartałów: } \\
\text { e. zachowanie możliwości koegzystencji oryginalnej zabudowy jednorodzinnej z zabu- } \\
\text { dową wielorodzinną, a w wybranych miejscach wprowadzenia nowej zabudowy wielo- } \\
\text { rodzinnej. }\end{array}$ & tak & - & tak \\
\hline $\begin{array}{l}\text { 3. Zbudowanie ciągów funkcjonalnych wzdłuż ulicy Warszawskiej (część centralna; } \\
\text { proponowana jako ulica Henryka Wojciechowskiego), a także wzdłuż ulicy Żelaznej i } \\
\text { Warszawskiej (część północna). }\end{array}$ & tak & - & tak \\
\hline $\begin{array}{l}\text { 4. Znacząca poprawa dostępności pieszej i komunikacyjnej, a także uzupełnienia } \\
\text { struktury dróg rowerowych. }\end{array}$ & tak & - & tak \\
\hline \multicolumn{4}{|c|}{ Zasadnicze założenia koncepcji Miejscowego Planu Rewitalizacji (MRP) } \\
\hline $\begin{array}{l}\text { 5. Drobne, lecz znaczące przestrzennie, uzupełnienia zasobów zieleni publicznej - } \\
\text { głównie rejon Skweru Sybiraków oraz ciąg ulicy Warszawskiej (część centralna). }\end{array}$ & tak & - & tak \\
\hline $\begin{array}{l}\text { 6. Przemodelowanie otoczenia dworca PKP i dworca autobusowego w celu wytworze- } \\
\text { nia w taki istotnym miejscu przestrzeni integracyjnej, akomodacyjnej i reprezentacyjnej. }\end{array}$ & tak & tak & tak \\
\hline 7. Korekty ciągów pieszych i ich integracja z ciągami funkcjonalnymi. & tak & - & tak \\
\hline $\begin{array}{l}\text { 8. Reorganizacja ruchu kołowego z przeniesieniem ruchu obwodowo w stosunku do } \\
\text { tkanki mieszkaniowej (w tym poprawa bezpieczeństwa układu drogowego). }\end{array}$ & tak & tak & tak \\
\hline 9. Rozwiązanie problemu deficytu miejsc postojowych / parkingów. & tak & tak & tak \\
\hline \multicolumn{4}{|l|}{ Założenia uzupełniające wskazane w procesie partycypacji } \\
\hline Zwiększenie udziału zieleni wewnątrz obszaru rewitalizacji & - & tak & * \\
\hline Ustanowienie standardów dla instalacji grzewczych (eliminacja lub redukcja emisji) & - & tak & * \\
\hline Poprawa jakości infrastruktury (głównie kanalizacja deszczowa) & - & tak & * \\
\hline Konieczność uzupełnienia systemu dróg (połączeń) rowerowych & - & tak & * \\
\hline Eliminacja sklepów monopolowych & - & tak & * \\
\hline $\begin{array}{l}\text { Potrzeba zwiększenia ilości placówek usługowych, zwłaszcza gastronomii (odtworze- } \\
\text { nie usług i handlu ze wsparciem administracji lokalnej - ulgtp.itp.) }\end{array}$ & - & tak & * \\
\hline $\begin{array}{l}\text { Eliminacja lub znacząca redukcja ruchu kołowego w ulicy Warszawskiej (część cen- } \\
\text { tralna) }\end{array}$ & - & - & * \\
\hline Wprowadzenie większej ilości miejsc dla dzieci (place tp.aw itp.) & - & - & * \\
\hline
\end{tabular}

Przyjęcie proponowanych zmian wynikających z badania ankietowego pokazuje ilustracja $\mathrm{nr} 7$.

\section{WNIOSKI - PODSUMOWANIE}

Ograniczenia wynikające z prawa własności, komplikacje wynikające z ograniczeń przestrzennych oraz zaangażowanie samorządu w już realizowane lub zrealizowane projekty, które uprzednio nie były korelowane z procesem rewitalizacji, znacząco zmieniają stopień efektywności translacji wyników ankiety na koncepcję (cf. Tormenta Pinto 2013, 1449-1450). Nie czyni to ankiety mniej ważną, lecz pozostającą w pełni równoprawną. Wprowadzenie ankiety do tych dwóch etapów w rozpatrywanym przypadku stanowi pomoc przy realizacji zamierzenia urbanistycznego i pozwala zwrócić uwagę na wiodące zagadnienia problemowe $\mathrm{w}$ ujęciu, w ramach którego wytwarzana jest społeczna świadomość uwarunkowań towarzyszących decyzjom projektowym. Oznacza to, że społeczność posiada wiedzę nie tylko o projekcie, ale jego przyczynach i uzasadnieniu dla jego kształtu.

Rola ankiety w projektowaniu urbanistycznym jest wieloraka, co można stwierdzić biorąc pod uwagę sposób, w jaki funkcjonowała ona w projekcie „Starówki” w Wołominie:

1. Ankieta wprowadza do powszechnego użytku (co najmniej lokalnej społeczności) system pojęciowy konieczny do prowadzenia dyskursu na tematy projektowe, systematyzuje inne elementy nazewnictwa, naturalnie nie w ścisłym tego słowa znaczeniu - w ujęciu logicznym - 
lecz wystarczająco kierunkującym absorpcję definicji, by większość zagadnień poruszanych w dyskursie była komunikatywna dla odbiorców, niezaznajomionych z dyscyplinarnym językiem architektury.

2. Ankieta, by być skuteczną, musi mieć w miarę lakoniczną postać, wygodną dla respondenta do wypełnienia. To oznacza, że nie może być zbyt długa. Zwięzłość każe zatem ważyć słowa i ograniczać pytania do tych najistotniejszych. Respondent staje przed wydestylowanym materiałem, zwracającym mu uwagę na to, co według zamawiającego i projektanta najważniejsze i do tego się odnosi. Można na tej podstawie wysnuć wniosek, że informacyjną rolę ankiety, skupioną na badaniu potrzeby interwencji i jej pożądanych form (Rosiak Ł. 2016, s. 41-55), suplementują inne formy partycypacji, lepsze w pozyskiwaniu swobodnych komentarzy, idei, spostrzeżeń na kwestie niezdefiniowane przez projektanta. Naturalnie można sobie wyobrazić składniki ankiety mające postać pytań półotwartych (w których respondent może dopisywać własne uwagi), ale przy ankiecie jest to formuła nieefektywna, jest bowiem niezbyt koherentna z zasadniczą formą odpowiedzi na pytania ankietowe - konkretną, posegregowaną, ujednoznaczniającą nawet wówczas, gdy nie do końca poszczególne odpowiedzi oddają intencje respondenta.

3. Ankieta nie działa jako jedyny element polityki informacyjnej oraz podłoża odpowiedzialnego za tworzenie obrazu projektu i kontekstu tego projektu (jego znaczeń, czynników wpływających na jego formowanie, których respondenci mogą nie być świadomi). Niemniej ankieta pozwala konstruować i ewentualnie korygować hierarchię ważności zadań, jakimi projektanci mają się zająć.

4. Dla projektanta, ale także innych uczestników procesu decyzyjnego, istotne jest ustalenie, jak hierarchia kryteriów oceny rozwiązania projektowego, proponowana przez projektanta uczestnikom, powinna się zmienić, zanim stanie się podstawą do dokonywania nieodwracalnych rozstrzygnięć architektonicznych lub urbanistycznych. Konieczne jest zatem skalibrowanie ocen wydawanych przez odbiorców projektu, a w konsekwencji doprowadzenie do ustandaryzowania wyników ankiety (o czym wspomniano w powyższym pkt. 3). Ta kalibracja odbywa się w szczególności za pośrednictwem drugiej ankiety, pierwsza jest bowiem rozpoznaniem hierarchii problemów tak, jak widzą je respondenci. Można podsumować te rozważania tak, że projektant rozpoznaje hierarchię problemów, następnie proponuje hierarchię remediów, dokonuje ich translacji na materialną, przestrzenną postać uzupełnioną opcjonalnie o regulacje prawne, i zwraca hierarchię komponentów programowo-przestrzennych. Na tę hierarchię reagują ( $w$ ankiecie ewaluacyjnej) respondenci, pozwalając na jej kalibrację, zmianę, adaptację ostatecznie formuje się koncepcja w możliwie większym stopniu odzwierciedlająca synergię idei projektanta i potrzeb odbiorców. W taki sposób dociera się do pkt. 5, wskazanego poniżej.

5. Ankieta poprzez jednostkę odnosi się potrzeb do zbiorowości mając na uwadze korzyści dla własnego środowiska.

We współczesnym projektowaniu urbanistycznym wykorzystującym partycypację społeczną i szerszy udział konsultacyjny istotną rolę odgrywa znajomość różnych metod i technik badawczych. Biura projektowe prowadzą różnorodne działania wykorzystujące potencjał jaki ukryty jest w metodzie i wdrażają ją do pracy przy podejmowaniu decyzji. Jak zauważa Henry Sanoff trzeba było uspołecznić architekturę aby: służyła zaspokajaniu potrzeb, które często są ignorowane poprzez organizacje, instytucje biurokratyczne oraz "ekspertów” zajmujących się planowaniem i projektowaniem. Podsumowując zebrany i opisany w poszczególnych rozdziałach materiał można uznać, że ankieta jest jedną z najprostszych form pozyskiwania informacji. Badanie takie pozwala na dotarcie do dość dużej grupy reprezentatywnej poprzez dodatkowe sposoby np. metodę kuli śnieżnej. ${ }^{4}$ Dobrze dobrane pytania skutkować będą trafnymi odpowiedziami i pełniejszym zrozumieniem tematyki o jaką jest pytany respondent. Im będą prościej sformułowane pytania tym prostszych, bardziej trafnych odpowiedzi można się spodziewać. Faktem jest także wiele mankamentów tej techniki. Jednym z nich jest brak gwarancji na wiarygodność wyników. Ankietowany może przelać

\footnotetext{
${ }^{4}$ Metoda kuli śnieżnej - (ang. snowball sampling) - metoda nielosowego doboru próby polegająca na rekrutowaniu uczestników przez innych uczestników.
} 
na kwestionariusz ankietowy swój aktualny stan emocjonalny, który nie odzwierciedla jego prawdziwych emocji w odniesieniu do treści kwestionariusza (Szyjewski Z. 2018, s. 147-162).

Z przeprowadzonych badań zastosowania dwuetapowej ankiety w procesie projektowania urbanistycznego wysuwają się wnioski, które można określić jako pozytywne i negatywne. W dotychczas prezentowanym wycinku całego procesu projektowego badanie to można uznać jako element dopełniający spostrzeżenia projektantów. Ogólnym czynnikiem jakiegokolwiek badania jest potrzeba wiedzy. Urbaniści oprócz dotychczasowych metod związanych z kształtowaniem środowiska skorzystają z wiedzy innych użytkowników tego procesu (Rosiak Ł. 2018, s. 33-48). Bazując na wiedzy zdobytej od odbiorców tworzyć będą projekty oparte, nie tylko na przestrzennych możliwościach podpartych nadzieją na akceptację, ale urzeczywistnioną w formie, akceptowaną przez większość interesariuszy (Rosiak Ł. 2014, s. 38-45).

Dostrzec można również bardzo istotną różnicę w miejscu włączenia ankiety do całego procesu. W pierwszym etapie miejscem włączenia ankiety są czynności początkowe. Drugi etap to czynności końcowe. Jeden i drugi moment włączenia ankiety jest poprawny. Wszystko zależy od zawartości włączanej ankiety. Jej treść musi być adekwatna do badanego punktu z całego procesu.

\section{BIBLIOGRAPHY}

Arnstein S. R., Drabina Społecznej Partycypacji, [in:] Magazyn Amerykańskiego Instytutu Planistów, 1969.

Barełkowski R., Techniki informatyczne w architekturze $i$ urbanistyce, Ośrodek Wydawnictw Naukowych, Polska Akademia Nauk, Poznań, 2001.

Barełkowski R., Rozdzieranie przestrzeni. Partycypacyjna odpowiedzialność czy partycypacyjna prywata, Przestrzeń i Forma/Space \& Form, no. 45, Polska Akademia Nauk Department in Gdańsk, Szczecin 2021, 77-108.

Barełkowski R., Problemy implementacji projektowania partycypacyjnego w Polsce, Przestrzeń i Forma/Space \& Form, no. 22, Polska Akademia Nauk Department in Gdańsk, Szczecin 2014, 25-46.

Barełkowski, R., Barełkowska, K., Struktura metody planowania przestrzennego P.R.S. - podstawy teoretyczne, w R. Barełkowski (red.), Przestrzeń architektury a przestrzeń kulturowa, Ośrodek Wydawnictw Naukowych, Poznań, 2003, 7-22.

de Carlo G., An Architecture of the Participation, Critical Theory of Architecture in the Twentieth Century, Caleidoscópio, Casal de Cambra, 2011, s. 753-758.

Czekiel-Świtalska E., PUBLIC CONSULTATION IN LOCAL PLANNING - SELECTED ISSUES/Konsultacje społeczne w planowaniu miejscowym - wybrane zagadnienia, [in:] Przestrzeń i Forma/Space \& Form no. 17, Polska Akademia Nauk Department in Gdańsk, Szczecin 2012, 325-338.

Hajduk S., Partycypacja społeczna w zarządzaniu przestrzennym, Oficyna wydawnicza Politechniki Białostockiej, Białystok 2021.

Haklay M., Jankowski P., Zwoliński Z., Selected Modern Methods and Tools for Public Participation in Urban Planning - A Review, Quaestiones Geographicae, 37(3), 127-149.

Hou J., Citizen Design: Participation and Beyond, [in] T. Banerjee i A. Loukaitou-Sideris (eds.), Companion to Urban Design. chapter 25, London: Routledge, 2011, 329-340.

Jacobs A., Appleyard D., Toward an Urban Design Manifesto, Journal of the American Planning Association, 53(1), 1987, 112-120.

Kaus M., Rosiak Ł., Partycypacja społeczna w małych ośrodkach gminnych jako czynnik zrównoważonego rozwoju w kreowaniu przestrzeni, w W. Marzęcki (red.), Przestrzeń i Forma, 27, Polska Akademia Nauk Oddział w Gdańsku, Szczecin 2016, s. 117-129.

Kaus M., Rosiak Ł., Wróblewska-Jachna J., Postrzeganie bydgoskich przestrzeni publicznych przez lokalnych odbiorców jako wstęp do partycypacyjnego procesu projektowego, w W. Marzęcki (red.), Przestrzeń i Forma, 33, Polska Akademia Nauk Oddział w Gdańsku, Szczecin 2018, s. 141-158.

Rosiak Ł., Relacje architekta i inwestora wpływające na ksztaltowanie przestrzeni, [in:] Przestrzeń i For$\mathrm{ma} /$ Space \& Form no. 44, Polska Akademia Nauk Department in Gdańsk, Szczecin 2020, $129-142$.

Rosiak Ł., Partycypacyjna metoda projektowania architektonicznego - kazus wstępnej fazy implementacji metody AdLS, [in:] Przestrzeń jako laboratorium. Perspektywy, studia, interwencje, ed. Robert Barełkowski, Wydawnictwo Exemplum, Poznań 2014, 38-45. 
Rosiak Ł., Architektura i czynny udział społeczeństwa w decydowaniu o jakości przestrzeni życia, w Z. Bać (red.), Habitaty: reaktywacja małych społeczności lokalnych, Wrocław 2014, s. 284-293.

Rosiak Ł., Od ogółu do szczegółu, czyli od spotkania do czynnego udziału w projektowaniu partycypacyjnym, w R. Idem (red.), Przedmiot, architektura, miasto. Nauczanie w sztukach projektowych, Wydawnictwo Uczelniane Politechniki Koszalińskiej, Koszalin 2016, s. 41-55.

Rosiak Ł., The significance of early stages in participatory design for social sustainability, w C. A. Brebbia S. Hernandez (red.) Eco-Architecture 2016, 6th International Conference on Harmonisation between Architecture and Nature, 13-15 July 2016, Wessex Institute of Technology, WIT Press, Southampton \& Boston.

Rosiak Ł., Misja architekta w projektowaniu partycypacyjnym, w W. Marzęcki (red.), Przestrzeń i Forma, 36, Polska Akademia Nauk Oddział w Gdańsku, Szczecin 2018, s. 33-48.

Sanoff, H., Community Participation Methods in Design and Planning, John Wiley and Sons, New York, 2000.

Sanoff H., Integrowanie programowania ewaluacji i partycypacji w projektowaniu architektonicznym. Podstawy teorii Z, Poznań 1999.

Suchomska J, Kołacz P., Przepis na plan, Fundacja Pracownia Badań i Innowacji Społecznych „Stocznia”, Toruń 2016.

Szyjewski, Z., Metody badania zachowań społecznych. Studia i Prace WNEIZ US, 54/2, 2018, 147-162.

Tormenta Pinto, P., Social Participation in the Context of the Urban Public Space Renewal: The Case of Lagarteiro Neighbourhood in Oporto, Journal of Civil Engineering and Architecture, Vol. 7, No. 11 (72), 2013, 1445-1457.

Wołomin, Plan Rewitalizacji starówki https://wolomin.org/miejscowy-plan-rewitalizacji-starowka-spacer-i-codalej/ Accessed on 29.11.2021.

Miejscowy plan rewitalizacji - drugi etap konsultacji: https://wolomin.org/miejscowy-plan-rewitalizacji-drugietap-konsultacji/ Accessed on 29.11.2021.

Porozmawiajmy o podwórkach - konsultacje w Szczecinie: https://stocznia.org.pl/projekty/porozmawiajmy-opodworkach-konsultacje-szczecinie/ Accessed on 29.11.2021.

Konsultacje Społeczne, decydujemy z mieszkańcami: http://wojskapolskiego.szczecin.eu/konsultacjespoleczne-2/ Accessed on 29.11.2021.

Strategia rozwoju miasta 2012-2020 w Będzinie: https://partycypacjaobywatelska.pl/strefa-wiedzy/przykladydzialan/strategie-rozwoju/strategia-rozwoju-miasta-2012-2020-w-bedzinie/ Accessed on 29.11.2021.

Młodzież w laboratorium partycypacji „Rimpiazza”: https://partycypacjaobywatelska.pl/strefa-wiedzy/przykladydzialan/przestrzen-publiczna/mlodziez-w-laboratorium-partycypacji-rimpiazza-rewitalizacja-placusantissima-annunziata-florencja/ Accessed on 29.11.2021.

Miejski Plan Likwidacji Barier - Valdemoro: https://partycypacjaobywatelska.pl/strefa-wiedzy/przykladydzialan/przestrzen-publiczna/miejski-plan-likwidacji-barier-valdemoro-hiszpania/ Accessed on 29.11.2021.

Planning for Real(TM) na wyspie Sheppey: https://partycypacjaobywatelska.pl/strefa-wiedzy/przykladydzialan/przestrzen-publiczna/planning-for-realtm-na-wyspie-sheppey-wielka-brytania/ Accessed on 29.11.2021.

\section{AUTHOR'S NOTE}

Łukasz Rosiak - assistant lecturer at the Bydgoszcz University of Science and Technology, architect, member of KPOIA RP, SARP, TUP. The scientific activity has two directions of interestedcations. The first is the participatory design. Another direction of interest is the contact of contemporary architecture and historic tissue.

\section{O AUTORZE}

Łukasz Rosiak - asystent, nauczyciel akademicki na Politechnice Bydgoskiej im. Jana i Jędrzeja Śniadeckich w Bydgoszczy, architekt, członek KPOIA RP, SARP, TUP. W działalności naukowej realizuje dwa kierunki zainteresowań: pierwszym jest projektowanie partycypacyjne, a drugim styk architektury współczesnej z tkanką zabytkową.

Contact | Kontakt: lukasz.rosiak@pbs.edu.pl 